\title{
Problem based Learning: An Experience of Evaluation based on Indicators, Case of Electronic Business in Professional Career of Systems Engineering
}

\author{
César Baluarte-Araya, Ernesto Suarez-Lopez, Oscar Ramirez-Valdez \\ Academic Department of Systems and Informatics Engineering \\ Universidad Nacional de San Agustín de Arequipa, Arequipa, Perú
}

\begin{abstract}
It is a reality that universities place great emphasis on formative research in the training of their students in order to increase their knowledge, skills, attitudes and achieve competences. This paper aims to show the experience of applying the Problem-Based Learning (PBL) methodology to assess learning based on indicators that have been determined from the criteria considered to correspond to the competences of the course under study Business Electronic, at the Professional School of Systems Engineering (EPIS) of the Universidad Nacional de San Agustín de Arequipa (UNSA), Arequipa-Peru, with theory and laboratory practice taught by two teachers. The objective is to apply an evaluation strategy for the development of competences with active didactics to the engineering training course. The methodology used is Problem-Based Learning applied to a formative research project based on real problems common to many organizations. In the semester, the students in groups solve the problems stated, and then they deliver a deliverable report and formative research report of each problem that is scored through a rubric. The teachers make contributions and provide feedback in the report for the improvement and experience that the student is acquiring in their training. The results obtained show that the objectives are achieved, increasing knowledge, skills, attitudes and adequate evaluation in the training of students, as well as the development of the competences of the course, as well as achieving the results of the student; showing that the application of PBL with Formative Research would provide good results for other courses of the professional career, allowing continuous improvement in the teaching-learning process. The conclusion is that an adequate assessment of learning based on indicators with an active didactic strategy, effectively planned and adequately applied to real-life problems, makes it possible to achieve the expected student results.
\end{abstract}

Keywords-Problem-based learning; formative research; competences; evaluation; performance indicator; skills; deliverable report

\section{INTRODUCTION}

At the university higher education level, universities try to achieve accreditation to guarantee the quality of the service offered. In Peru, accreditation is available through the National System of Evaluation, Accreditation and Certification of Educational Quality (SINEACE) [1] for all areas of knowledge; the area of engineering tries to adapt to other international standards such as [2] and others recognised by SINEACE such as [3], [4], [5].

Universities are applying formative research in order to allow their students to achieve a suitable level of research in their professional training as part of their competences to increase their knowledge and thus apply it to solving problems in reality. Thus, the Universidad Nacional de San Agustín de Arequipa [6], Arequipa - Peru, its Educational Model is based on the competency-based model for the professional training of students, and take into account that Professional Schools, such as the Professional School of Systems Engineering [7], teachers must include Formative Research in the syllabus of the course, in order to eliminate gaps in knowledge, skills and attitudes in students, and thus be able to use didactic strategies [8],[9],[10] adapting them to the nature of the course in order to achieve the training objectives and competences.

Since 2019, the EPIS has begun the accreditation process through the Accreditation Board for Engineering and Technology (ABET). And the stage of self-assessment was completed in 2020. Consequently, the authors of this article proposed to apply active teaching strategies as an action of continuous improvement in the development of their subjects. It is necessary for the student to develop greater knowledge, other skills, attitudes and training competences of the courses, as well as to achieve a higher level of research. The experience is developed in the subject Electronic Business (NE) which corresponds to the VIII semester of the Study Plan.

The objective pursued is to apply the evaluation based on indicators to each Deliverable Report and Formative Research Report, by using the PBL as an active strategy in the solution of laboratory problems in the NE course, by the working groups formed in the course within the teaching-learning process.

The research carried out is descriptive and the methodology is based on the stages of the scientific method for problem solving [11], which states that the student has access to develop skills, as we would say greater knowledge, procedures and values.

As a result of working in groups and applying PBL, the students developed each of the problems posed. The students 
recognise that they have been evaluated in each report in the fairest and most objective way by the indicators that make up each criterion and the criteria that make up each competence of the course.

The conclusions reached are that the Problem-Based Learning methodology is appropriate for its application because of the nature of the course, which allows autonomous learning, increases knowledge of the problem area, strengthens the development of skills and attitudes, enables students to perform well, and achieves the expected student outcomes of the course; it also strengthens research training.

The article is organized in the Section II of Related Works Context of the Experience, in Section III the Methodology is treated, in Section IV the Design of the Project of PBL and Formative Research is shown, in Section $\mathrm{V}$ the Method of Work is shown, in Section VI the Results of the work are shown, in Section VII the Discussion that is made is touched, that they worked or investigated others and of the result that is obtained that contributes in the formation of the student, in Section VIII the conclusions of the work are shown, in Section IX the future works that can be carried out are shown.

\section{RELATED WORK: CONTEXT OF THE EXPERIENCE}

\section{A. Challenges in the Current Situation}

The author of the present work; as well as the teachers who develop the courses with him; set out to accept the challenge of formally applying the Formative Research together with the Active Didactic Strategies from 2019 in the courses that it is his turn to develop in the EPIS.

In the current situation the evaluation of work or projects is done based on the criteria that make up the evaluation rubric, not performing a more detailed, real, fair, and evolution and monitoring that should be done to each student or group of students work that allows a better feedback to them of the deliverable reports for continuous improvement. Having thus the problem defined and to be treated for its solution in the present work.

\section{B. Formative Research}

In this regard [12] states that formative research nurtures research by generating future researchers, and defines it [13] as the pedagogical strategies carried out to train in and for research based on the appropriate activities of the scientific method, and the opinion that focuses on the strategy of learning by discovery and its construction [14], with the student at the centre of the process [15], with the teacher playing the role of advisor in the demand for and rigorousness of research.

On this subject [13] emphasises that the pedagogical function focuses attention on Formative Research, which is derived from the university's mission to generate both theoretical knowledge and knowledge on the application of knowledge to solve problems of reality. The problem of the teaching-research relationship must be addressed, contemplating the role that research must play in the learning process. It also reflects that Formative Research is linked to the concept of training, placing us in the field of teaching strategies that of shaping, structuring something that is built throughout the process, which in this case refers to the training of students who are trained through the various activities developed to understand and advance through Formative Research in deepening scientific research in their professional training. In the educational process of formative research, the actors directly involved are teachers and students.

We have previous experience in the EPIS in a first level of formative research in a speciality course in the courses of Writing Research Articles and Reports (RAII), Research Methods and Writing, (MIR), having as deliverables the elaboration of posters and documentary research articles, reports of results, and Formative Research Report; this allows to develop in the student the acquisition of new knowledge, skills and training competences.

Thus, in order to achieve a higher level of research, it is determined that in the NE course taught in the 8th semester of the Study Plan, the Problem-Based Learning (PBL) methodology is applied to deal with the different problems close to reality and having as a result the Deliverable and Formative Research Report of the problems solved by each working group of students.

For the present work, the NE course is taken as a case study, applying PBL in the laboratory sessions using techniques, methodologies and tools for the resolution of each problem dealt with, producing the respective Deliverable Report and Formative Research Report using the established template, which will be evaluated with the relevant rubric.

In Formative Research, by applying active learning strategies, learning is participatory, student-centred and employing active methodologies such as PBL. The author in [16] considers in Formative Research Management establishing mechanisms for integrating the research process into the teaching-learning process by designing methodological mechanisms. Likewise [17] analyses the role of Formative Research in the development of undergraduate scientific competences, how students perceive the contribution and impact of the professional training process in the development of their research competences. It is worth mentioning that since 2014 there have been the first results of the experience in the EPIS of the start in Formative Research with [18-19] evidencing and validating in [20] the achievement of the students of delivering as a result articles or posters of documentary research in events, of managing to develop the soft skills and also the competences of the course.

\section{Student Competence Development}

A curriculum based on competences implies that these are adequately developed in the students, considering that the advantages of PBL related to the acquisition, development and duration of competences by students trained with the methodology as referred to by [21] for different degrees or contexts are well known, which we would say we contemplate in Table I for better visualisation.

Very interesting is what is referred to by [22] when quoting (Vargas, S. 2010) where "competences, in addition to intellectual aspects, incorporate skills and attitudes ...", the aim is to master knowledge focused in a global and integral way of the person. 
TABLE I. COMPETENCIES ADDRESSED BY RESEARCHERS

\begin{tabular}{|l|l|l|}
\hline Competencies & Researcher(s) & Year \\
\hline Development of critical thinking skills & $\begin{array}{l}\text { Koh, Khoo, Wong y Koh } \\
\text { Şendağa y Odabaşi } \\
\text { Tiwari, Lai, So y Yuen }\end{array}$ & $\begin{array}{l}2008 \\
2009 \\
2006\end{array}$ \\
\hline The highest degree of self-efficacy & Rajab & 2007 \\
\hline $\begin{array}{l}\text { Self-perceived competencies } \\
\text { Cohen-Schotanus, } \\
\text { Muijtjens, Schönrock- } \\
\text { Adema, Geertsma y van } \\
\text { der Vleuten }\end{array}$ & 2008 \\
\hline $\begin{array}{l}\text { Cognitive and social competencies } \\
\text { Processing strategies } \\
\text { Metacognitive self-regulation } \\
\begin{array}{l}\text { Regulation of effort } \\
\text { Peer learning }\end{array}\end{array}$ & Koh et al. & 2008 \\
\hline $\begin{array}{l}\text { Long-term impact of measures } \\
\text { on competencies acquisition }\end{array}$ & $\begin{array}{l}\text { Sungur y Tekkaya } \\
\text { der Molen }\end{array}$ & 2006 \\
\hline $\begin{array}{l}\text { Clinical reasoning } \\
\text { Scaffa y Wooster }\end{array}$ & 2004 \\
\hline
\end{tabular}

In other words, competence involves the development of knowledge, skills and attitudes in a specific area of knowledge, which, with the application of PBL, increases procedural skills, valuing achievements, learning from experiences when carrying out research [25] in the students' professional training.

Furthermore, as proposed by [23] in a methodology with control points and evaluation mechanisms, the results obtained demonstrate progress in the competences for solving real-life problems, managing projects, determining and discovering shortcomings, and allowing weaknesses in the teaching process of future engineering professionals to be corrected; noting that better results can be obtained throughout the curriculum with the support of the teachers.

\section{Problem based Learning}

In [20] referring to [2] who mentions that future graduates must be able to work in a global context, in multidisciplinary teams, solve problems and that what is learned is constantly changing, therefore, their training requires constant updating.

An appropriate concept contemplated by [24] when referring to Barrows (1986) who defines PBL as "a learning method based on the principle of using problems as a starting point for the acquisition and integration of new knowledge".

PBL as a didactic strategy used in universities is widely accepted in the area of engineering, it advocates cooperative or collaborative activities of active interaction between students and the student with the teacher who acts as a facilitator of learning; working in small groups of 4 to 8 members, oriented to the student who is the centre of attention of the strategy [14] [25], dealing with problems of reality in a systematic way seeking their solution through analysis, observation and evaluation, strengthening their knowledge of the area being treated.

PBL was born in the mid-1960s [23] for medical professionals to develop competencies and skills to master real-world problems. There are different methods as referred to in [14]. Morales and Landa [24] consider the following steps to be followed for its application: (a) analyse the problem scenario, (b) brainstorm, (c) list what is known, (d) list what is not known, (e) list what needs to be done to solve the problem, (f) define the problem, (g) obtain and process information and (h) present results.

There are many experiences related to the application of PBL in different areas, such as [15] in the subject of systems analysis, in basic sciences such as Physics [26], in Engineering such as Chemistry [27]. Experiences of applying PBL, such as those of [28] at the University of Murcia, Spain, within the process of convergence towards a European Higher Education Area (EHEA), as well as [29] in Computer Science, and [30] in the area of Mathematical Sciences.

In order to work with PBL, we have the approach of [24] and [31] that propose the steps for students to work with PBL, providing activities that can be evaluated, such as: team and individual work, written report, individual and team contribution, self-evaluation.

PBL has fundamental characteristics that come from the model developed at McMaster as referred to in [24] which among others are:

- Learning is student-centred.

- Learning takes place in small groups of students.

- Teachers are facilitators or guides.

- Problems form the focus of organisation and stimulus for learning.

- Problems are a vehicle for the development of problem-solving skills.

- New information is acquired through self-directed learning.

Producing significant changes in students by promoting, developing collaborative work culture, interpersonal skills, student participation, valuing teamwork, interdisciplinary work, problem identification skills, critical thinking, formative assessment.

\section{E. Assessment for Learning}

In this regard, there are the experiments referred to in [21] by the studies carried out by (De Grave, Boshuizen and Schmidt, 1996; De Grave, Schmidt and Boshuizen, 2001) where they refer that students obtain better scores when they analyse the problem before gathering information, as opposed to those who only do so on the basis of the material provided.

It is convenient to refer to [22] when he states that learning assessment is an integral and continuous process of diagnosis and training, with criticality, retrospection, introspection and projection of the learning process; considering the basic questions of What, How, When, When, Who to assess, which allows determining the type of assessment according to the context where it is developed. As a reference, we also have the contribution of [32], whose questions break down the basic questions into sub-subheadings.

Table II shows the basic criteria for quality evaluation from the point of view of [33]. 
TABLE II. CRITERIA FOR QUALITY ASSESSMENT

\begin{tabular}{|l|l|}
\hline Criteria & It means to the students \\
\hline Transparency & $\begin{array}{l}\text { Clarity of criteria and levels of demand, allows him to } \\
\text { orient his work, self-evaluate his own learning pace. }\end{array}$ \\
\hline Validity & $\begin{array}{l}\text { It assures you that the assessment system assesses the } \\
\text { learning outcomes it is supposed to assess and not others. }\end{array}$ \\
\hline Fiability & $\begin{array}{l}\text { It is not enough to value what must be valued, but it must } \\
\text { also be done in the right way. }\end{array}$ \\
\hline Democratic & Participate actively in the teaching-learning process. \\
\hline Global & $\begin{array}{l}\text { That it is an essential part of their learning process, } \\
\text { integrated into the curriculum and a task that is continuous } \\
\text { and not just for a special moment. }\end{array}$ \\
\hline Formative & $\begin{array}{l}\text { It will serve you as motivation, orientation of your work } \\
\text { pace. }\end{array}$ \\
\hline
\end{tabular}

Source: Available at [37].

In this regard, it is important to note what [2] says from the point of view of programme accreditation "Assessment of student learning, with a focus on continuous improvement, is key to ensuring the quality of our educational programs and preparing our graduates to enter a global workforce. The cumulative result of student learning in our curricula and cocurricular activities enables the career and professional accomplishments of our graduates. In an era of accountability and transparency, outcomes assessment has become an international standard of quality".

Bearing in mind that EPIS teachers are immersed in the application of active didactic strategies to assess student results that are immersed in the ABET accreditation model for the development of student competences.

In the evaluation of learning when applying PBL in the teaching-learning process by competences, instruments are applied according to the context of the reality of the problems to be solved, in the present work the rubric [34, 35, 36, 37] was used to evaluate through indicators that determine in the results the achievement of knowledge, the level of development of competences, attitudes, using rating scales, in an objective and consistent way of the activities.

The author's knowledge in active didactic learning strategies is given by the constant study, adaptation and application of changes in the study materials, the forms of course development and the forms of evaluation that lead to demonstrate how the student achieves the expected results and develops the competencies of both the course and his professional training profile, and not only achieve an overall grade to pass a course. Taking into account that the results of its application are a contribution for the researchers of the scientific community, and through its analysis allows continuous improvement within the teaching-learning process.

\section{Methodology}

The methodological design used is quasi-experimental, not working with a control group. The research is applied to solve the problem of the qualification of the results through the Deliverable Report and Formative Research Report. The research developed uses the PBL methodology, the rubric instrument, the scoring tool for the indicators of each criterion in each subject competence.
There are many definitions for indicators. UNE 66.175 (2003) defines it as "Data or set of data that help to objectively measure the evolution of a process or an activity".

\section{DESIGN OF THE PLB AND FoRMATIVE RESEARCH}

The main characteristic of PBL is the use of a set of problems that are developed and given to students in small groups to promote learning, so the subject was adapted to the methodological principles of PBL, contemplating the application of the evaluation system based on indicators from [38].

The design of the project considered aspects such as relevance, dealing with real-life problems, helping students to increase their knowledge, applying methodologies, methods, techniques and tools related to the course, including formative research activities, allowing students to prepare structured reports for objective and fair evaluation.

In this regard, in [23] it is stated what should be taken into account in the design of the PBL, and most authors agree that there are a series of basic steps that may vary depending on: a) number of students, b) time available, c) objectives to be achieved, d) available bibliography, e) available resources of the teacher and the entity.

\section{A. The Project}

The project to be developed has the following characteristics:

- It contains problems of real-life organisations.

- The work team is made up of 4 or 3 students.

- The problems will be developed throughout the academic semester.

\section{B. The Problem}

According to [14], a good problem formulation or approach should consider 3 variables: a) Relevance, so that students understand the importance of the problem, b) Coverage, to guide students to search for, discover and analyse the information on the topic of study, c) Complexity, as there is no single solution, several hypotheses should be put forward, testing and documenting them.

A series of problems were adapted in the course to respond to the objectives, the development of the contents of each subject, the development of competences, the reinforcement of skills and the achievement of student results.

Considering the different scenarios of the type of real organisations, both business and governmental, where the student assumes the different roles when participating in the work team to develop the problems.

The characteristics of well-structured problems are referred to by [38] citing Romero M. and J. García-Sevilla (2008) and contemplated by citing (Ching and Chia, 2005), which are very valuable in their contribution.

\section{Project Problem Issues}

The topics to be covered in the problems are: 
- Virtual stores.

- Customer Relationship Management CRM.

- Supply Chain Management SCM.

- E Marketplace.

- E Learning.

- E Employee.

- E Government.

- M Business.

The development of the problems in the laboratory sessions of the NE course was determined either by groups of students made up of 4 or 3 members, taking into account in its conformation: the willingness to meet, communication, work schedules for the sessions, taking into account the other courses of study of the team members, coincidence of personal interrelation; which gives very good results.

\section{Tracking}

In the development of the course during the semester, there are sessions for the delivery of the Deliverable Report and Formative Research, where the result of the problem, its exposition and evaluation are reflected, providing feedback so that the team of students can make corrections and take into account the opinions and suggestions that will be useful for the development of future problems.

The role played by the teacher is that of a guide by giving guidelines, suggestions, orienting, suggesting sources of information and being willing to collaborate with the needs of the students in the team.

\section{E. Evaluation}

If we start from the concept and function of an indicator, which normally occurs at the level of an institution, as contemplated by [39], and if we adapt and apply them to the level of a subject performance indicator that allows us to evaluate the problems posed to students.

The most general characteristics of these indicators are: objective, relevant, useful, precise, congruent, contextualised; that they provide data to generate information, make the changes to which they give rise and be useful for reporting on the changes that arise between inputs and results, point out the strong and weak points in the criteria, compare the results of the most and least successful experiences shown in each Deliverable Report, analyse the results for changes in the development of the course in future versions, discover other aspects related to the actions of the students that improve the application of PBL to the course.

In this case, the indicators will be useful when they are used to evaluate the results of the students' work with the aim of improving the teaching process and therefore the development of their competences.

For the year 2020, based on the Educational Model for competence-based vocational training, assessment is envisaged for the area of engineering using the rubric as an instrument for assessing competences and student results in the NE course.
Considering that with the rubric a better result is possible, achieving the objectives and measuring performance. Taking into account what is stated by [34] as a point to carry out learning and assessment work, and also by [35] that provides the provision for the student to be constant as to how far to go with their learning of the topics and what would be their desired maximum level; with the purpose of:

- Achieving the student outcomes determined for the subject.

- Achieve the development of the competences defined for the subject.

- Strengthen the development of soft skills, attitudes and values in the student.

- Establish achievable goals, deliverable reports and formative research.

- Develop the problems by applying the PBL established for the subjects.

- Follow-up and feedback by the teacher from the Deliverables Reports and Formative Research in the evaluations of the same for continuous improvement.

- Increase the interpersonal and social relations of the members of the team or working group.

- Manage the activities and time for the development of the problem, obtaining the results, the elaboration of the Deliverable.

Fig. 1 shows the format of the evaluation matrix in its first part of the header.

Fig. 2 shows the second part of the evaluation matrix, the detail of the format, which is the basis for the elaboration of the evaluation matrix in an electronic spreadsheet.

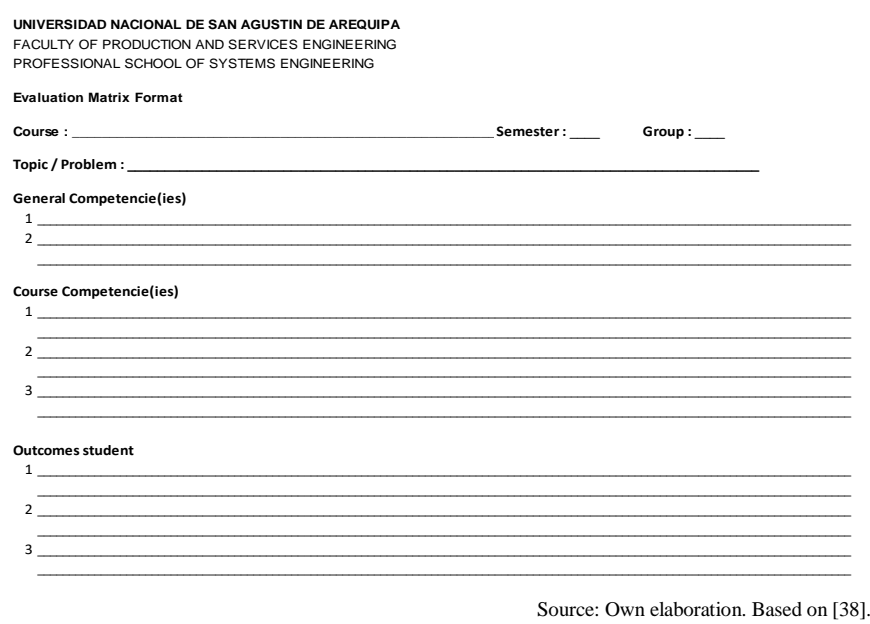

Fig. 1. Header of the Evaluation Matrix Format. 


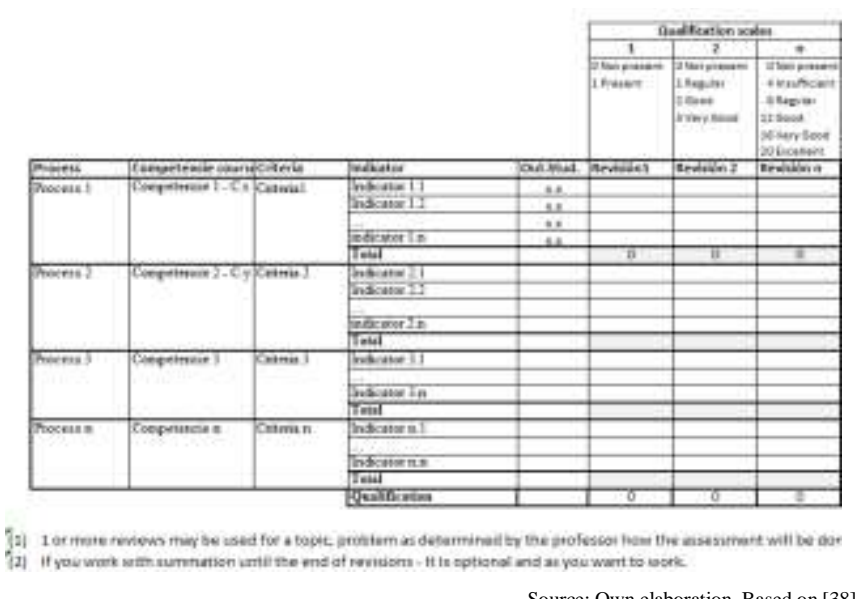

Source: Own elaboration. Based on [38].

Fig. 2. Detail of the Evaluation Matrix Format.

\section{F. Grading}

For the grading of the Deliverables and Formative Research Reports, the indicator-based evaluation system proposed by [38] was followed. The initial structure was adapted to include the element "student outcomes", which is considered important and better complements its definition, structure and application to the evaluation of problems or projects; namely: a) General Competence(s) (from the graduate profile), b) Course Competence(s), c) Student Outcomes, d) Process(es), e) Criterion(s), f) Performance Indicator(s), g) Indicator(s) Rating Scale; having that the rating scales are applied according to the nature of the indicator in each criterion and each competence involved in the subject.

The Grading Scales Table for Assessment proposed in [38] is used, in input scales 5 or 6 values can be adopted according to the determined grading level, which is shown in Fig. 3.

\section{G. Conversion - Rubric Grading Scale Equivalence}

Converts from the grading scale to the scale of the rubric established to be reflected in the student's results grade and the semester evaluation periods.

UNIVERSIDAD NACIONAL DE SAN AGUSTIN DE AREQUIPA

FACULTY OF PRODUCTION AND SERVICES ENGINEERING

PROFESSIONAL SCHOOL OF SYSTEMS ENGINEERING

Table of Qualification Scales for Evaluation

No. Entries

\begin{tabular}{|c|c|c|c|c|c|c|}
\hline \multirow[b]{3}{*}{2} & & & & & & \\
\hline & Not present & Present & & & & \\
\hline & 0 & 1 & & & & \\
\hline \multirow[b]{2}{*}{3} & Not present & Regular & Good & & & \\
\hline & 0 & 1 & 2 & & & \\
\hline \multirow[b]{3}{*}{4} & Not present & Regular & Good & Very Good & & \\
\hline & Not present & Regular & Good & Excellent & & \\
\hline & 0 & 1 & 2 & 3 & & \\
\hline \multirow{5}{*}{5} & Not present & Regular & Good & Very Good & Excellent & \\
\hline & Not present & Insufficient & Regular & Good & Excellent & \\
\hline & 0 & 1 & 2 & 3 & 4 & \\
\hline & 0 & 2 & 6 & 8 & 10 & \\
\hline & 0 & 5 & 10 & 15 & 20 & \\
\hline \multirow{4}{*}{6} & Not present & Insufficient & Regular & Good & Very Good & Excellent \\
\hline & 0 & 1 & 2 & 3 & 4 & 5 \\
\hline & 0 & 2 & 4 & 6 & 8 & 10 \\
\hline & 0 & 4 & 8 & 12 & 16 & 20 \\
\hline
\end{tabular}

Note: Qualification scales can be assembled according to the nature of the criterion or indicator. Source: [38].

Fig. 3. Table of Qualification Scales for Evaluation.

\section{METHOD OF WORK}

\section{A. Conceptual Design}

There is a good experience of one of the authors of this work [40] in applying Project Based Learning that serves as a reference to apply active strategies in the teaching-learning process in the NE course in the professional career of Systems Engineering.

The purpose is for the student to research, carry out searches, review analogous scenarios, examine diverse literature, select, organise, analyse, interpret data and information, and be able to propose alternative solutions to the real problem posed in an organisation, using the PBL strategy to reinforce and discover greater knowledge, develop soft and procedural skills, and evaluate the results obtained.

The research for development is based on the problemsolving stages of the scientific method, which together with the active didactic strategy of PBL, allows the student to develop skills such as those discussed in [38] where good results were obtained.

In order to obtain data on the students' perception, the survey technique is applied and the questionnaire is used as an instrument, the results are systematised and analysed so that the conclusions can be used to take actions for the continuous improvement of the learning process. are:

The stages determined for the development of the project

\section{Stages of the project}

1. Starting point

Theme:

- Dealing with Reality Problems in Electronics Business.

Initial Question

- iFrom the knowledge obtained and with the knowledge acquired from e-Business, will it be possible to solve the problems posed from the real context in the organisations?

2. Formation of Collaborative Teams

- Team/group of 4 or 3 students.

3. Definition of the Final Product

Product to be developed

- Solving real context problems in organisations.

What you need to know (learning objectives)

- Apply Problem Based Learning to solve the problems posed.

- To elaborate the report of each deliverable applying the template defined for it.

- To carry out the presentation of the solution of the problem 


\section{Planning}

- Determination of the competences of the course.

- Alignment of the competences to the learner outcomes.

General student competences:
C.x Competence r.
C.y Competence $\mathrm{p}$.

Course competences Electronics Business:
a Competence a of the course.
b Competence $b$ of the course.

Student outcomes to be assessed:

a) Criterion RE.7.2. Student outcome 7.2 of competence a.

b) Criterion RE.8.2. Student outcome 8.2 of competence $b$.

Competence Criteria and Indicators

Criterion 1 Indicator 1 Student Outcome 1. Indicator 2 Student Outcome 1.

Criterion 2 Indicator 3 Student outcome 2. Indicator $\mathrm{n}$ Student outcome $\mathrm{m}$.

5. Organising Team/Group Work

Team or group work of 4 or 3 students.

6. Review / Development of Problems (Laboratory Guides)

7. Instruction in PBL methodology

In the first class session, it is explained.

8. Application of the PBL methodology

- Presentation of the problem situation.

- Laboratory guides to solve problems.

- Answering queries in the session by the means determined.

- Carrying out the activities and tasks of the problem.

- Presentation of deliverables.

- Oral presentation of results of the deliverable.

9. Elaboration of the Deliverable and Formative Research Report

Elaboration of the report according to the elaboration template.

10. Evaluation of the report and competences

- The teacher in the sessions evaluates the competences and the results of the student, to the group through the grading tool based on the rubric.

- Assessment of the Deliverable Report and Formative Research Report of each problem through the rubric-based grading tool.
11. Initial Evaluation of the Application of the PBL Methodology

At the conclusion of the first development phase of the semester.

12. Final Evaluation of the Application of the PBL methodology

At the end of the third phase of the semester.

Apply the questionnaire to receive the student's perceptions.

\section{Methodologies, Techniques and Instruments to be Used}

Methodologies, Techniques and Instruments

- Problem Based Learning Methodology - PBL.

- Problem solving, in sessions established within the development of the course.

- Survey technique.

○ Questionnaire - of students' perception of PBL.

○ Questionnaire - students' perception of the application of PBL to the e-Business course. o Questionnaire - students' perception of the application of PBL to the Electronics Business course.

- Questionnaire - on tutor's perception of the tutor's work.

Evidence

- Digital files of lab work.

- Moodle, Virtual Classroom as a repository of course work.

\section{Assessment Instruments}

- Written report grading tool.

- Assessment rubrics.

- Evaluation of Competences and Student Outcomes.

Student self-assessment, by general appreciation.

\section{B. Participants}

The course of NE in the professional career of Systems Engineering is developed in the eighth semester (4th year), with 5 hours per week, 3 of them theoretical and 2 of laboratory, the semester is developed in 17 weeks; participating in the evaluation of the Deliverable Report and Formative Research, taking as a case the semester $2020 \mathrm{~B}$ with a total of 35 students; the theory and laboratory practices were in charge of two teachers, forming two groups of theory and ten laboratory subgroups.

\section{Data Analysis Technique}

From the evaluation of the Deliverable Report and Formative Research, they were graded with the grading tool generated for it contemplating the structure based on the 
evaluation system based on indicators of [38], application of questionnaires to students to get appreciation data, systematization of data in the electronic spreadsheet EXCEL, analyzing the results achieving averages, tables, and graphs.

\section{Instruments}

The instruments used are:

- Laboratory Guides.

- Template for the elaboration of the Deliverable Report and Formative Research.

- Evaluation rubrics.

- Grading tool for the written report of the NE course.

- Student Achievement Appreciation Questionnaire.

\section{E. Techniques}

Evaluation techniques are used:

- The rubric.

- The Rating Scale.

- Survey.

\section{F. Deliverables}

The deliverables that correspond to each of the topics indicated in the point Project Problem Topics were determined, which are developed and delivered by each team or working group, and stored in the virtual classroom repository. The evaluation of which is graded with the grading tool and with immediate feedback in the report to strengthen the teachinglearning process, the development of competences and the achievement of student outcomes.

The structure of the Formative Inquiry and Deliverable Report is shown below:

\section{Cover page}

Index

1. Plan the treatment of the problem

2. Organising the work of the team/group

3. Problem

4. Theoretical framework

5. Comparative of the selection of aspects

6. Working in a group, collaboratively with colleagues and avoiding working alone

7. Generation of possible solutions (Alternatives)

8. Presentation of the solution

9. Prototype or Situational Analysis

10. Lessons Learned

11. Conclusions

12. References

13. Annexes

14. Report

15. Self-evaluation.

\section{RESULTS}

The results of the Evaluation of the Deliverable and Formative Research Report (EDRFR) are shown below; with a defined and used structure, based on the defined rubric of the NE course. A sample is shown in Fig. 4, where the general competences (of the student or of the graduate profile), the course competences related to the general ones, the criteria, the indicators of the criteria with the rating scale determined for each one of them, and their rating for the proposed problem of the working groups can be seen.

Fig. 5 shows the evolution of two of the 66 indicators in the group's progress in developing each problem during the semester.

Fig. 6 shows the evolution of the Students' Results related to the course competence a, of the General Competence r. Where it can be seen how groups 1,2 and 4 have a growing tendency to obtain the maximum grade close to 20, and group 5 remains at a level with a grade value of 15 between 12 and 15.

Fig. 7 shows the group grades for the Student Outcomes related to competences $\mathrm{a}$ and $\mathrm{b}$ of the course, of the General Competences $r$ and $\mathrm{p}$. Here it can be seen that groups 1, 2 and 10 have an average grade of 18 on the vigesimal scale for competence a, and group 5 has an average grade of 14 .

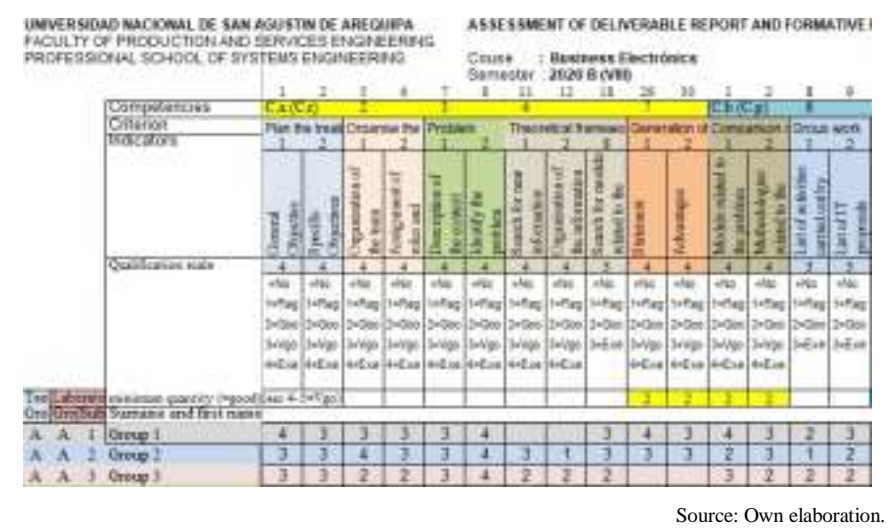

Fig. 4. ADRFR - Report Qualification Tool.

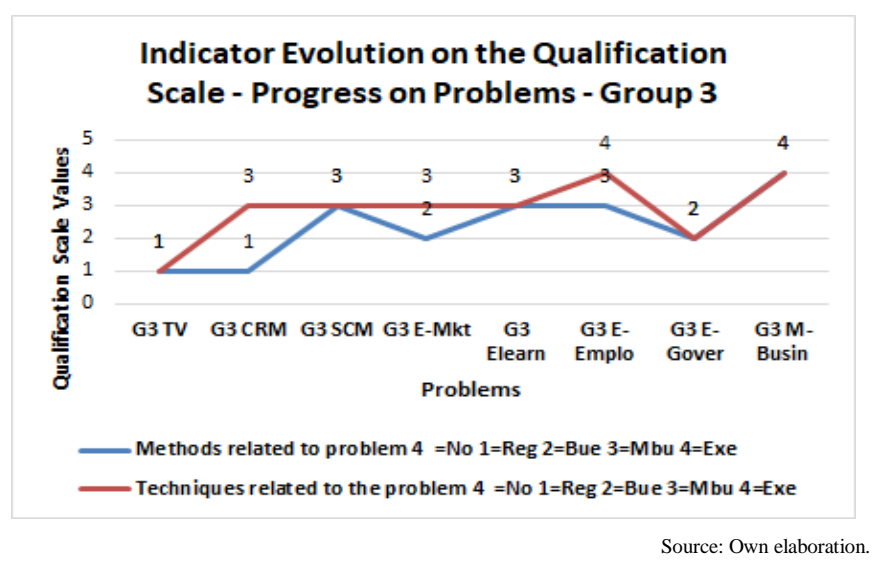

Fig. 5. IEQS-PP-HG3 - Report Indicator Evolution. 


\section{Evolution of Student Outcomes - Competence a}

(r)

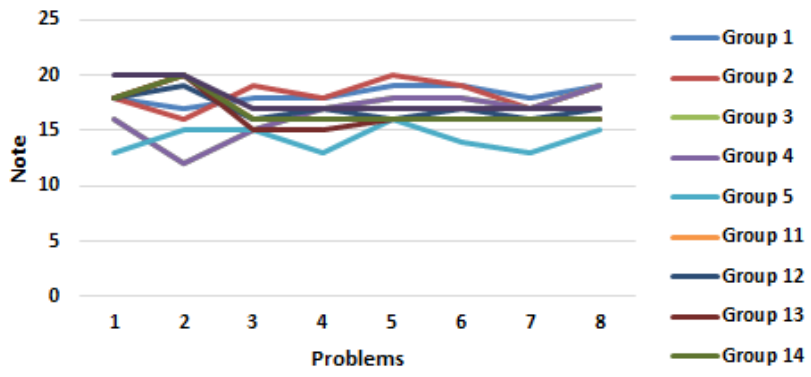

Source: Own elaboration

Fig. 6. ESO - Report Evolution Outcomes - Competence a.

Student Outcome Notes - Competence a ( $r)$ b (p)

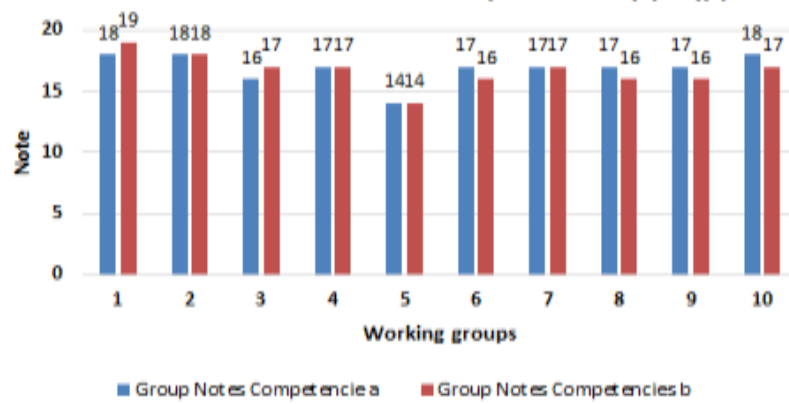

Source: Own elaboration.

Fig. 7. SON-Report Student Outcome Note - Competence $\mathrm{a}$ and $\mathrm{b}$.

Fig. 8 shows the good results as an average of the evaluation of one problem: Virtual Shops, taking into account the levels of the assessment scale of the rubric criteria, which are also used for the other 7 problems.

Fig. 9 shows the evolution of working group 3 in the development of each of the problems during the academic semester.

\section{Evaluation Deliverable Report and Formative Research - Assessment Scale - Rubric Criteria Problem: Virtual Shops}

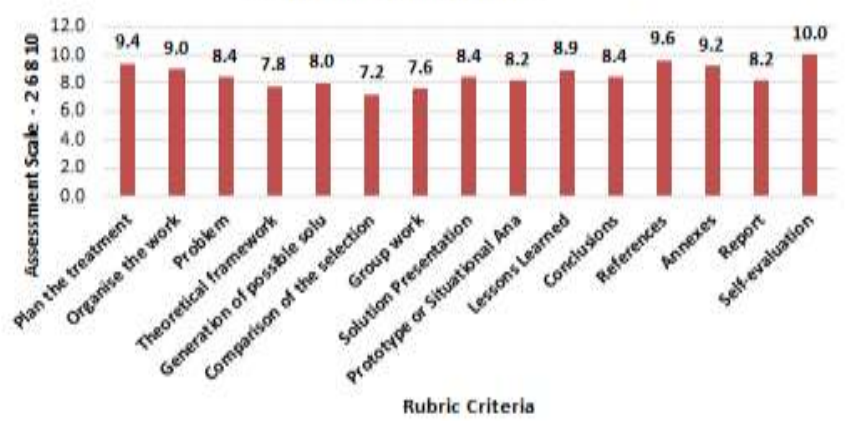

Source: Own elaboratio

Fig. 8. EDRFR - Evaluation Deliverable Report and Formative ResearchAssessment Scale-Rubric Criteria-Problem:Virtual Shops.
Evaluation Deliverable Report and Formative Research - Assessment Scale - Problems Group 3

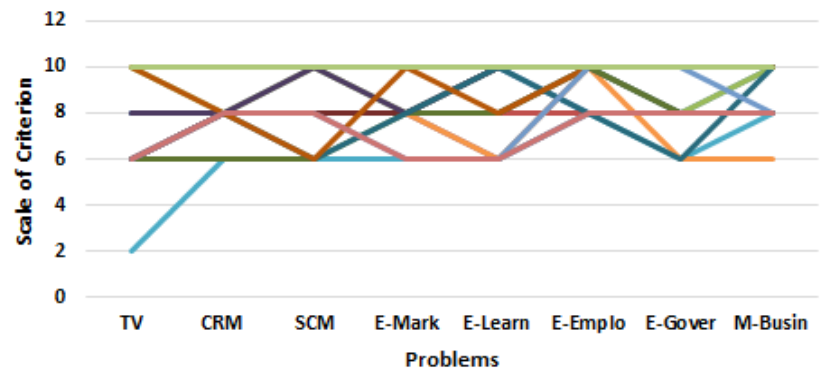

Source: Own elaboration

Fig. 9. EDRFR - AS - PG3 - Evaluation Deliverable Report and Formative Research-Assessment Scale-Problems Group 3.

\section{VII.DISCUSSION}

It is important in engineering education to consider the statement by [28] that "University education is the last educational step before professional practice..." Therefore, in order to exercise a profession, the graduate must be competent. This means that in order to solve real-life problems, he/she must possess knowledge, soft and procedural skills, ingenuity, among others. Being of the opinion that PBL and the assessment process greatly favour the development of complex competences.

The application of PBL was born for the development of competencies and skills in the training of professionals in the area of medicine for the mastery of real problems in the mid1960s; however, it is still applied with relevant adaptations as discussed by [41] in their study in the field of Clinical Laboratory Medicine, where the problem is that there is a large gap between theoretical concepts and clinical laboratory practice, and in actual clinical practice. Faced with this they reorganized the cases of PBL in hematology studies, defining the processes of design, preparation, implementation and evaluation of PBL. Concluding that it incorporates a strong way to safeguard the gap between theory and practice, so students make good use of their medical science training toward solving complicated problems. The results show that PBL encouraged students to interact, pose questions, state hypotheses, find out answers, and evaluate their ability to prove their points.

Having that [42] in their work on formative research provide some reflections that are necessary to take into account such as: they seek that in their processes students become familiar with scientific and research culture; training them in research skills; interaction, dialogue and research practice are mandatory; formative research is positioned in academic and formative activities in universities. Concluding that formative research; referring to (Arakaki, 2009); is fundamental for the professional formation of the student with critical, reflective and proactive thinking, by stimulating the ability to raise and respond to unresolved problems or scenarios of the environment. 
When referring [24] to teachers in higher education, very few have training in pedagogy and teach as they were taught; or as we say, take the best university lecturer as a reference point; and active methodologies are not applied and assessment is limited to checking the memorisation of facts and information. In view of this, in order to apply PBL, changes are required in the role of the teacher, who becomes a facilitator so that students build their knowledge and apply it in real situations.

Thus, [21] mentions that there is experimental verification when students start from the analysis of a problem prior to the documentary study, they achieve much higher marks in the learning evaluations, compared to what others do with the same material; in the present work the verification is made through the activities and the results obtained.

There are results on the development of research competences by applying research strategies from [17] in research training. The author in [13] points out the importance of formative research as a means of pedagogical function in the production of knowledge.

In [43], the result of the research is directed to university teachers who wish to apply didactic strategies that affect the book in explaining the didactic discipline, being the didactic strategies focused on meeting the objectives set in a teachinglearning context.

In [44] the application of PBL in the university level course they decided to rethink the way of working because the experience showed them that something was failing in the learning of students in the last 10 years, they proposed to change and go beyond a simple evaluation. This contributes to the fact that when faced with a similar situation, the problem should be analyzed and the feasibility of using didactic teaching and learning strategies applied to the context of reality should be assessed.

In the research work it has been achieved to apply PBL as an active didactic strategy in the development of the NE course that contributes to the integral formation of the student, achieving the development of competences, allowing a better development in their formation and future work performance.

Also the PBL besides being applied in courses of a curriculum is used in other areas that are related to professional training and where the student participates as being the experience of [45] concluding that students participate in the planning of projects, development of skills, and that the PBL bridges the gap between learning and application; and thus the student effectively faces real world problems. Having that in our country, Peru, with the University Law No. 30220 of 2014 universities are obliged to work the University Social Responsibility that contributes to sustainable development and the welfare of society.

As an experience we have the results of the evaluation grades of the last three years, which shows how the qualification from indicators allows a fairer and more objective evaluation and growth of each deliverable of the students, when applying PBL from 2019, which are shown in Table III for better visualisation.
TABLE III. GRADE POINT AVERAGE

\begin{tabular}{|l|l|l|l|}
\hline \multirow{2}{*}{ Course } & \multicolumn{3}{|l|}{ Grade Point Average } \\
\cline { 2 - 4 } & $\mathbf{2 0 1 8}$ & $\mathbf{2 0 1 9}$ & $\mathbf{2 0 2 0}$ \\
\hline $\begin{array}{l}\text { Electronics Business } \\
\text { Theme: Mobile Business }\end{array}$ & 15.17 & 16.15 & 17.4 \\
\hline
\end{tabular}

VIII. CONCLUSION

The following conclusions have been reached:

- The course objectives have been achieved.

- The student outcomes determined for the course are achieved.

- Students achieve the development of the competences of the course and therefore favour the achievement of the competences of the syllabus.

- Problem-Based Learning as an active methodology allows: enhancing autonomous learning, increasing knowledge on topics by understanding them, applying the knowledge obtained, motivation and teamwork, strengthening the development of procedural skills and abilities, improving students' academic performance.

- Formative research in the student's professional training process is transversal in the courses of the curriculum, as in the case of the Database and Electronic Business courses, where the teachers of this work intervene, achieving good results.

- The students manage to have the appropriate evaluation from the qualification of each indicator involved in each problem, being the most objective, real and fair, going from less to more.

- The students recognise that what they have achieved in the development of the problems in the course will serve as a guideline for them to develop in future organisations.

- Providing the students with feedback in the reports of deliverables reviewed, graded and observations made by the teacher, allows them to continuously improve in the work group.

- The student at the end of the course has been able to carry out documentary research on the topics of the theoretical framework to increase their knowledge, and to conveniently write the Deliverable Report and Formative Research.

\section{FUTURE WORK}

- To carry out comparative research on the application of $\mathrm{PBL}$ in the courses of the Curriculum.

- Conduct comprehensive formative research in other Curriculum courses for the development of students' competences.

\section{ACKNOWLEDGMENT}

Our thanks to the Universidad Nacional de San Agustín de Arequipa for allowing and supporting the development of 
Formative Research, strengthening the formative area and the application of proposals for continuous improvement based on active didactic strategies that will benefit the students.

\section{REFERENCES}

[1] SINEACE, Sistema Nacional de Evaluación, Acreditación y Certificación de la Calidad Educativa https://www.gob.pe/sineace/

[2] ABET. Why ABET Accreditation Matters. https://www.abet.org/ accreditation/what-is-accreditation/why-abet-accreditation-matters/. Ultimo acceso junio 2021. https://www.abet.org/ assessment/

[3] ICACIT, Instituto de Calidad y Acreditación de Programas de Computación, Ingeniería, Tecnología https://www.icacit.org.pe/web/es/

[4] CNA, Consejo Nacional de Acreditación, Colombia. https://www.cna.gov.co/1741/articles-186359_pregrado_2013.pdf

[5] AcreditAcción, Agencia Acreditadora https://acreditaccion.cl/

[6] Universidad Nacional de San Agustín de Arequipa. http://www.unsa.edu.pe.

[7] Escuela Profesional de Ingeniería de Sistemas. http://www.episunsa.edu.pe.

[8] Subdirección de Currículum y Evaluación, Dirección de Desarrollo Académico, Vicerrectoría Académica de Pregrado, Universidad Tecnológica de Chile INACAP. (2017), pp. 21-24. Manual de Estrategias Didácticas: Orientaciones para su selección. Santiago, Chile: Ediciones INACAP.

[9] Rodriguez Cruz, Reyna, Compendio de estrategias bajo el enfoque por competencias, Instituto Tecnológico de Sonora ITESCA, México, 2007, pp. 26-29. http://www.itesca.edu.mx/documentos/desarrollo_ academico/compendio_de_estrategias_didacticas.pdf.

[10] Ma. Cristina Sánchez Martínez, Marcos Aguilar Venegas, José Luis Martínez Durán and José Luis Sánchez Ríos, Estrategias didácticas en entornos de aprendizaje enriquecidos con tecnología (antes del Covid19), UNIVERSIDAD AUTONOMA METROPOLITANAXOCHIMILCO, México, 2020, pp. 11-15.

[11] GARZA-RIVERA, RG. El rol de la física en la formación del ingeniero. Ingenierías, 2001, vol. IV, No. 13, pp. 48-54.

[12] Patiño, R. A., Melgarejo, Z.A. and Valero G.M. (2019). Percepción de los egresados contables sobre la investigación formativa. Revista Activos, 16(30), 101-125. DOI: https://doi.org/10.15332/25005278 .5062 , Colombia.

[13] Restrepo Gómez, Bernardo, INVESTIGACIÓN FORMATIVA E INVESTIGACIÓN PRODUCTIVA DE CONOCIMIENTO EN LA UNIVERSIDAD, Nómadas (Col), núm. 18, mayo, 2003, pp. 195-202, ISSN: 0121-7550, Universidad Central, Bogotá, Colombia.

[14] Restrepo Gómez, Bernardo, Aprendizaje basado en problemas (ABP): una innovación didáctica para la enseñanza universitaria, Educación y Educadores, vol. 8, 2005, pp. 9-19, Universidad de La Sabana, Cundinamarca, Colombia.

(DOI) http://dx.doi.org/10.18687/LACCEI2018.1.1.97

[15] Medina-Rojas, F., Nuñez-Santa, J.M., Sánchez-Medina, I.I. and Cabrera-Medina, J.M., Implementación del ABP, PBL y método SCRUM en cursos académicos para desarrollar sistemas informáticos enfocados en fortalecer la región, Revista Educación en Ingeniería, 12(24), pp. 52-57, Julio, 2017, Bogotá. ISSN 1900-8260 DOI: http://dx.doi.org/10.26507/rei.v12n24.758

[16] Mejía Murillo, Carmen, Manual de Procesos de Investigación Formativa, Universidad Herminio Valdizán, Perú, 2016, pp. 7-9.

[17] Pinto Santos, Alba and Cortés Peña, Omar, ¿Qué Piensan los Estudiantes Universitarios Frente a la Formación Investigativa?, REDU. Revista de Docencia Universitaria, 2017, 15(2), 57-75.

[18] Baluarte C., Vidal E., Delgado L. and Castro E.; Integrando Habilidades Blandas: Redacción, Comunicación y Ética en la Currícula de la Escuela Profesional de Ingeniería de Sistemas - UNSA; 15th LACCEI International Multi-Conference for Engineering, Education, and Technology: "Global Partnerships for Development and Engineering Education", 19-21 July 2017, Boca Raton Fl, United States. Digital Object Identifier (DOI): http://dx.doi.org/10.18687/LACCEI2017.1.1.141 ISBN: 978-0-99934430-9 ISSN: 2414-6390.
[19] Castro E., Vidal E. and Baluarte C., Integrando la Comprensión de la Responsabilidad Ética y Profesional en una Carrera de Ingeniería: Experiencia y Lecciones Aprendidas, 14th LACCEI International MultiConference for Engineering, Education, and Technology: "Engineering Innovations for Global Sustainability", 20-22 July 2016, San José, Costa Rica, RP139.

[20] Baluarte Araya, César., Vidal Duarte, Elizabeth and Castro Gutierrez, Eveling, Validación de las Habilidades Blandas en los cursos de la Currícula de la Escuela Profesional de Ingeniería de Sistemas-UNSA, 16th LACCEI International Multi-Conference for Engineering, Education, and Technology: "Innovation in Education and Inclusion", 19-21 July 2018, Lima, Perú. Digital Object Identifier (DOI): http://dx.doi.org/10.18687/LACCEI2018.1.1.97 ISBN: 978-0-99934431-6 ISSN: 2414-6390.

[21] Briones, Elena and Vera, Jesús, Aprendizaje Basado en Problemas (ABP): Percepción de carga de trabajo y satisfacción con la metodología, V Congreso Mundial de Estilos de Aprendizaje, Santander, España, https://dialnet.unirioja.es/servlet/articulo? codigo $=4640627$

2012

22] Acebedo, M.J. (2016). La evaluación del aprendizaje en la perspectiva de las competencias. Revista TEMAS, 3(11), pp. 203-226.

[23] Fernández, F.H and Duarte, J., El aprendizaje basado en problemas como estrategia para el desarrollo de competencias específicas en estudiantes de ingeniería, Formación Universitaria, 6(5), 2013, pp. 29 38.

[24] P. Morales and V. Landa, "Aprendizaje Basado en Problemas". Theoria, Vol. 13, 2004, pp. 145-157. [On line]. Disponible: http://biblioteca.udgvirtual.udg.mx/jspui/handle/123456789/574.

[25] C. Gamboa, "Apuntes sobre Investigación Formativa"; versión No. 2, Colombia, 2013. [On line]. Disponible: http://idead.ut.edu.co/Aplicativos/PortafoliosV2/Autoformacion/material es/documentos/u2/Apuntes_sobre_investigacion_formativa.pdf.

[26] Espinoza Suarez, Silvia, Effectiveness Of Problem-Based Learning In The Academic Performance of course Physics I, 16th LACCEI International Multi-Conference for Engineering, Education, and Technology: "Innovation in Education and Inclusion", 19-21 July 2018, Lima, Perú. (DOI): http://dx.doi.org/10.18687/LACCEI2018.1.1.226.

[27] Cañas Cano María, Aprendizaje Basado en Problemas (ABP), competencias y la enseñanza de química para Ingenieros, 16th LACCEI International Multi-Conference for Engineering, Education, and Technology: "Innovation in Education and Inclusion", 19-21 July 2018, Lima, Perú. (DOI): http://dx.doi.org/10.18687/LACCEI2018.1.1.66

[28] Vizcarro C. and Juárez E., La metodología del Aprendizaje Basado en Problemas, ¿Qué es y cómo funciona el aprendizaje basado en problemas?, Universidad de Murcia, España, 2008, cap. 1. http://www.ub.edu/dikasteia/LIBRO_MURCIA.pdf

[29] Farinazzo Valeria, Sampaio Paulo, Cordeiro Antonio and Ferreira Bruno, Implementing a Data Network Infrastructure Course using a Problem based Learning Methodology, Journal of Information Systems Engineering and Management, 2018 - Volume 3 Issue 2, Article No: 10 https://doi.org/10.20897/jisem.201810.

[30] N. Bedregal-Alpaca, D. Tupacyupanqui-Jaen, M. Rodriguez-Quiroz, L. Delgado-Barra, K. Guevara-Puente and O. Sharhorodoska, "ProblemBased Learning with ICT Support: An experience in teaching-learning the concept of derivative," 2019 38th International Conference of the Chilean Computer Science Society (SCCC), Concepcion, Chile, 2019, pp. 1-7. DOI: 10.1109/SCCC49216.2019.8966396

[31] Dirección de Investigación y Desarrollo Educativo, Vicerrectoría Académica, Instituto Tecnológico y de Estudios Superiores de Monterrey. "El Aprendizaje Basado en Problemas como técnica didáctica", pp.14-18, [On line]. Disponible: http://www.sistema.itesm.mx/va/dide/inf-doc/estrategias/

[32] F. Bermejo, and M.J. Pedraja, La metodología del Aprendizaje Basado en Problemas, La evaluación de competencias en el ABP y el papel del portafolio, Universidad de Murcia, España, 2008, cap.5.

[33] S. Grau C. and Gómez L. Ma.C., "La evaluación, un proceso de cambio para el aprendizaje". En: Evaluación de los aprendizajes en el Espacio Europeo de Educación Superior / Salvador Grau Company, Cecilia Gómez Lucas (Coord.). Alcoy: Marfil, 2010. ISBN 978-84-268-1523-1, 17-32. http://rua.ua.es/dspace/handle/10045/14937. 
[34] Octaedro, Rúbricas para la evaluación de competencias, España, 2013, pp. 8-23.

[35] Sáiz Manzanares, María Consuelo and Bol Arreba, Alfredo; Aprendizaje basado en la evaluación mediante rúbricas en educación superior, Elsevier, Suma Psicológica, SUMA PSICOL. 2014; 21(1):28-35, España, 2014.

[36] Ortega Andrade NA, Romero Ramírez MA and Guzmán Saldaña RME, Rubrica para evaluar la elaboración de un Proyecto de Investigación Basado en el Desarrollo de Competencias, Universidad Autónoma del estado de Hidalgo, México, 2014, vol.2, No. 4. https://www.uaeh.edu.mx/scige/boletin/icsa/n4/e6.html

[37] Ma.C. Sanchez Martinez, M. Aguilar Benegas, J.L. Martinez Durán, and J.L. Sánchez Ríos, Estrategias didácticas en entornos de aprendizaje enriquecidos con tecnología (antes del covid-19), Universidad Autonoma Metropolitana-Xochimilco, Mexico, 2020, pp.67-71.

[38] C. Baluarte-Araya, " Proposal of an Assessment System based on Indicators to Problem Based Learning - IEEE Conference Publication, Published in: 2020 39th International Conference of the Chilean Computer Science Society (SCCC), 16-20 Nov. 2020, Coquimbo, Chile. DOI: $10.1109 /$ SCCC51225.2020.9281203.

[39] J.M. Muñoz Cantero, and M.P. Rios de Deus, Indicadores de evaluación de la investigación en educación superior, REVISTA GALEGOPORTUGUESA DE PSICOLOXÍA E EDUCACIÓN, № 8 (Vol. 10) Ano $7^{\circ}$-2003 ISSN: 1138-1663.

[40] C. Baluarte-Araya, "Project based Learning Application Experience in Engineering Courses: Database Case in the Professional Career of Systems Engineering", (IJACSA) International Journal of Advanced
Computer Science and Applications, Volume 11 Issue 3, 2020, pp. 131140. DOI: 10.14569/IJACSA.2020.0110316.

[41] Xiandong Li, Fei Xie, Xiaoqiang Li, Guangwu Li, Xu Chen, Jun Lv, Chunyan Peng, Development, application, and evaluation of a problembased learning method in clinical laboratory education, Clinica Chimica Acta, Volume 510, 2020, Pages 681-684, ISSN 0009-8981. https://doi.org/10.1016/j.cca.2020.08.037. https://www.sciencedirect.com/science/article/pii/S0009898120304307.

[42] Jackeline Valencia, Jackeline Macias, Alejandro Valencia, Formative Research in Higher Education: Some Reflections, Procedia - Social and Behavioral Sciences, Volume 176, 2015, Pages 940-945, SSN 18770428. https://doi.org/10.1016/j.sbspro.2015.01.562. https://www.sciencedirect.com/science/article/pii/S1877042815005996.

[43] J. Flores, J. Avila, C. Rojas, F. Sáez, R. Acosta and C. Diaz, Estrategias Didácticas para el aprendizaje significativo en contextos universitarios, Unidad de Investigación y Desarrollo Docente, Dirección de Docencia, Universidad de Concepción, Chile, 2017, pp. 10-14.

[44] B. Santamarina, La evaluación de los estudiantes en la Educación Superior: Mas allá de la Evaluación, Universidad de Valencia, Servicio de Formación Permanente, España, 2007, pp. 49-53.

[45] Kuo-Huan Ting, Chung-Ting Cheng, Hou-Yi Ting, Introducing the problem/project based learning as a learning strategy in University Social Responsibility Program - A study of local revitalization of Coastal Area, Yong-An District of Kaohsiung City, Marine Policy, Volume 131, 2021, 104546, ISSN 0308-597X. https://doi.org/10.1016/j.marpol.2021.104546.

https://www.sciencedirect.com/science/article/pii/S0308597X21001573. 